\title{
THE EFFECT OF CANDESARTAN PRE-STROKE USE ON THE FUNCTIONAL OUTCOME OF POST ISCHEMIC STROKE PATIENTS IN BETHESDA HOSPITAL YOGYAKARTA
}

\section{PENGARUH RIWAYAT TERAPI CANDESARTAN PRASTROKE TERHADAP LUARAN FUNGSIONAL PASIEN STROKE ISKEMIK DI RUMAH SAKIT BETHESDA YOGYAKARTA}

\author{
Lise Insani Gulo $^{1 *}$, Rizaldy Taslim Pinzon ${ }^{2}$, Esdras Ardi Pramudita ${ }^{3}$ \\ ${ }^{1}$ Faculty of Medicine Duta Wacana Christian University Yogyakarta, JL. DR. Wahidin \\ Sudirohusodo 5-25 Yogyakarta 55224, Daerah Istimewa Yogyakarta \\ ${ }^{2}$ Bethesda Hospital Yogyakarta, Jalan Jendral Sudirman No. 70, Kotabaru, Gondokusuman, Kota \\ Yogyakarta, Daerah Istimewa Yogyakarta \\ ${ }^{3}$ Panti Rapih Hospital, Jl. Cik Di Tiro No.30, Caturtunggal, Kec. Depok, Kabupaten Sleman \\ 55223, Daerah Istimewa Yogyakarta
}

Received September 11, 2017; Accepted March 2, 2018

\begin{abstract}
Stroke is a leading cause of death and disability, where the main risk factor is hypertension. Angiotensin Receptor Blocker (ARB) is the most common drug for stroke prevention in high-risk hypertensive patients. The purpose of this study was to see whether the candesartan pre-stroke use can improve the functional outcomes of post ischemic stroke patients. The data were obtained from 191 retrospective observational studies. Data were collected from Stroke Registry and medical record at Bethesda Hospital Yogyakarta in 2014-2016, then analyzed univariate, followed by bivariate analysis using chi-square test, independent t-test and fisher exact test for the variable which has actual count (FO), and logistic regression for multivariate analysis. One hundred and ninety one samples were systematically reviewed to evaluate the effect of candesartan pre-stroke use on functional outcomes of post ischemic stroke patients in Bethesda hospital Yogyakarta whose range of ages was mostly between 61 and 70 years (30.9\%) and were mostly male patients (56.5\%). Patients with good functional outcomes $(<2)$ were $79.6 \%$ and poor functional outcomes $(\geq 2)$ were $20.4 \%$. The results of bivariate analysis showed that candesartan did not affect the improvement of clinical outcome (OR: 1.806, 95\% CI: 0.591-5.519, p: 0.294), and also not better than other angiotensin receptor blocker $(p=0.505, O R=1.472,95 \% C I=$ 0.470-4.611). The multivariate analysis showed that sex (OR: 0.366, 95\% CI: 0.156-0.858, p: 0.021), loss of consciousness (OR: 0.107, 95\% CI: 0.021-0.549, p: 0.007), limb weakness (OR: 0.236, 95\% CI: 0.067-0.834, p: 0.025), dyslipidemia comorbidity (OR: 2.750, 95\% CI: 1.1776.427, p: 0.019) and aphasia (OR: 0.342, 95\% CI: 0.107-1.100, p: 0.072) affected the functional outcome. The candesartan pre-stroke use did not improve the functional outcome of post ischemic stroke patient.
\end{abstract}

Keywords: angiotensin receptor blocker, candesartan, functional outcome, ischemic stroke, neuron protection

\section{ABSTRAK}

Stroke merupakan masalah neurologis yang menyebabkan kecacatan serta kematian yang tinggi, dimana faktor utama penyebabnya adalah hipertensi. Angiotensin Receptor Blocker (ARB) adalah salah satu obat pilihan utama untuk prevensi stroke pada pasien hipertensi. Tujuan dilakukannya penelitian ini adalah untuk melihat apakah riwayat terapi candesartan prastroke dapat memperbaiki luaran fungsional pasien paska stroke iskemik. Penelitian ini dilaksanakan

*Corresponding author: Lise Insani Gulo

Email: gliseinsani@gmail.com 
dengan menggunakan metode kohort retrospektif. Data diambil dari Stroke Registry dan rekam medis di Rumah Sakit Bethesda Yogyakarta pada tahun 2014-2016, kemudian dianalisis secara univariat, dilanjutkan analisis bivariat menggunakan uji chi-square test, uji-t independen dan uji fisher exact pada variabel yang memiliki actual count (FO), serta regresi logistik untuk analisis multivariat. Total jumlah sampel yang diambil pada penelitian adalah sebanyak 191 sampel dengan proporsi rentang usia terbanyak 61-70 tahun (30.9\%) dan berjenis kelamin laki-laki (56.5\%). Pasien dengan luaran fungsional baik (<2) adalah $79.6 \%$ dan luaran fungsional buruk ( 2) sebanyak 20.4\%. Analisis bivariat menunjukkan bahwa candesartan tidak mempengaruh perbaikan luaran fungsional pasien (OR:1.806, 95\%CI:0.591-5.519, p:0.294) dan tidak lebih baik daripada obat $A R B$ yang lain $(p=0.505, O R=1.472,95 \% C I=0.470-4.611)$. Hasil multivariat menyatakan jenis kelamin (OR:0.366, 95\%CI:0.156-0.858, p:0.021), penurunan kesadaran (OR:0.107, 95\%CI:0.021-0.549, p:0.007), kelemahan anggota gerak (OR:0.236, 95\%CI:0.0670.834, p:0.025), komorbid dislipidemia (OR:2.750, 95\%CI:1.177-6.427, p:0.019) dan afasia (OR:0.342, 95\%CI:0.107-1.100, p:0.072) mempengaruhi luaran fungsional pasien. Riwayat terapi candesartan prastroke tidak memperbaiki luaran fungsional pasien setelah stroke.

Kata kunci: angiotensin receptor blocker, candesartan, luaran fungsional, stroke iskemik, proteksi neuron

\section{INTRODUCTION}

Stroke is a neurological problem that causes disability and death and ranks as the first cause of deaths in Indonesia (CDC, 2016). Subarachnoid hemorrhage strokes are found on $1.4 \%$ of patients, intracerebral hemorrhage strokes are found on $18.5 \%$ of patients, and ischemic strokes are found on $42.9 \%$ of patients (Kusuima, 2009). Hypertension is one of the main risk factors that a person may experience a stroke, specifically in the Special Region of Yogyakarta, the number of hypertension increases from $8.3 \%$ in 2007 to $12.8 \%$ in 2013. Therefore, to control hypertension is needed to prevent the incidence of stroke (Yastroki, 2016; Riset Kesehatan Dasar, 2013). The effects of several anti-hypertension options are more than simply lowering down the blood pressure, such as ARB which protects the brain by its mechanism to lower the blood pressure, but also by the AT 2 receptor's improved performance which occurred due to the blockade of AT 1 receptor.

Angiotensin receptor blockers have been examined to have anti-inflammatory effects on the brain that mostly occur in the stroke patients, the two main processes that cause brain inflammation are peripheral infection and direct cell injury as a consequence of metabolic changes in the brain parenchyma while the presence of ischemia, however, in each ARB drug option is believed to have different efficacy in reducing the brain inflammatory of the ischemic stroke patients. Candesartan is one of the ARB drug options that is still controversial in recovering the functional outcomes of the ischemic stroke patients so that the researchers are keen to assess whether candesartan is able to improve the functional outcomes of the post ischemic stroke patients (Chrysant and Chrysant, 2006; Tziomalos et al., 2014).

\section{METHODS}

The research was carried out at the Bethesda Hospital, Yogyakarta, starting from February to April 2017, by using the retrospective cohort study as the method. Ischemic stroke patients were divided into two main groups namely the group of patients with the record of using pre-stroke candesartan and the group of patients with the record of using other anti-hypertension besides candesartan. The selection of the patients was conducted by using the purposive sampling technique in accordance with the existing criteria of inclusion and exclusion. The selected samples 
were the patients who had been diagnosed using the cranial CT scan; who had the results of modified ranking scale (mRS) upon discharge; who had experienced the primer stroke onset and at the onset of less than 24 hours when hospitalized; and whose record of patients' data showed that they used angiotensin receptor blocker (ARB) type of anti-hypertension before the stroke onset, which was taken and then a sub-analysis was conducted to assess whether the candesartan was better than the other ARB drug choices. The patients who returned home at their own request, referral patients, and patients with incomplete medical record, were not taken as samples.

The research was conducted by using the instruments, such as patients' data forms and stroke registry with a minimum 53 samples per group. However, after the research was running, the comparison was altered into 1:4 so that the minimum number of the candesartan group was 21 patients and noncandesartan of anti-hypertension group was 85 patients (Sullivan and Soe, 2007). Then, the obtained samples were analyzed using univariate analysis in order to look at the samples' characteristics, followed by a bivariate analysis and then multivariate analysis to look at which variables that affected the patients' functional outcome significantly.

The data processing was conducted in the Clinical Epidemiology and Biostatistics Unit (CE\&BU) Faculty of Medicine Gadjah Mada University by firstly taking the samples based on the criteria of inclusion i.e. all ischemic stroke patients diagnosed by using cranial CT scan and having the mRS results upon discharge so that the patients who were forced to discharge were excluded from the research. The selected patients had to have a candesartan therapy record and other prestroke hypertension and had experienced primer stroke with the onset of less than 24 hours. The referral patients from other hospitals, patients having incomplete medical data record, and those who were not recorded in the registry data had been excluded from the research.

\section{RESULTS AND DISCUSSION}

There were 191 samples analyzed by using a descriptive, bivariate and multivariate analysis. Based on Table I, the data of patients with a good functional outcome $(\mathrm{mRS}<2)$ was obtained, as much as $79.6 \%$ (152 samples) and a poor functional outcome ( $\mathrm{mRS} \geq 2$ ) with the amount of $20.4 \%$ (39 samples) or $56.5 \%$ of male and $43.5 \%$ of female. The analysis was followed up by using a bivariate analysis and then multivariate analysis aimed to analyze the significance of the variables toward ischemic stroke patients' functional outcome recovery. At this stage, the significance of the variables was seen from the value of $p$, if the value of $\mathrm{p}<0.05$, the variables were declared significant. On the contrary, if the value of $p>0.05$, the variables were declared not significant.

The total number of the samples taken in this research was 191 samples and as presented in Table I, it was seen that the incidence of stroke commonly occurred at the age between 61 and 70 years $(30.9 \%)$, in which $56.5 \%$ of the patients were male. The stroke onset events were mostly at the duration of 3-6 hours $(31.9 \%)$ and $93.7 \%$ of the total samples did not experience loss of consciousness, $\quad 170$ samples (89\%) experienced aphasia and 144 samples $(75.4 \%)$ experienced limb weakness. The patients having dyslipidemia comorbidities (52.9\%) were more than those having comorbidities of atrial fibrillation $(3.1 \%)$, while the total number of the patients experiencing complications was 83 samples $(43.5 \%)$, the number of patients having complications on urinary tract infection and decubitus was 2 samples $(1 \%)$ of the total samples on each category. The total number of patients who got neuroprotection therapy was $37.7 \%$ of the total samples and the patients with a record of using pre-stroke candesartan were to $15.7 \%$, while the percentage of patients recorded to have used other anti-hypertension was $89.5 \%$ in which the sub-analysis was conducted to those two groups on the patients with a record of using only ARB drugs and then compared to the other ARBs to assess whether candesartan was a better choice than the other ARBs. 
Table I. Basic Characteristics of the Research Subjects

\begin{tabular}{|c|c|c|}
\hline The Characteristics of the Patients & $\mathrm{n}=191$ & $(\%)$ \\
\hline \multicolumn{3}{|l|}{ Ages } \\
\hline$<40$ years old & 2 & 1.0 \\
\hline $40-50$ years old & 32 & 16.8 \\
\hline 51-60 years old & 56 & 29.3 \\
\hline $61-70$ years old & 59 & 30.9 \\
\hline$>70$ years old & 42 & 22.0 \\
\hline \multicolumn{3}{|l|}{ Gender } \\
\hline Female & 83 & 43.5 \\
\hline Male & 108 & 56.5 \\
\hline \multicolumn{3}{|l|}{ Candesartan } \\
\hline Yes & 30 & 15.7 \\
\hline No & 161 & 84.3 \\
\hline \multicolumn{3}{|l|}{ Anti-hypertension non- candesartan } \\
\hline Yes & 171 & 89.5 \\
\hline No & 20 & 10.5 \\
\hline \multicolumn{3}{|l|}{ mRS Nominal } \\
\hline good mRS & 152 & 79.6 \\
\hline bad mRS & 39 & 20.4 \\
\hline \multicolumn{3}{|l|}{ Onset } \\
\hline$<3$ hours & 34 & 17.8 \\
\hline 3-6 hours & 61 & 31.9 \\
\hline 6-12 hours & 49 & 25.7 \\
\hline 12-24 hours & 47 & 24.6 \\
\hline$>24$ hours & 0 & 0 \\
\hline \multicolumn{3}{|l|}{ Loss of Consciousness } \\
\hline Yes & 12 & 6.3 \\
\hline No & 179 & 93.7 \\
\hline \multicolumn{3}{|l|}{ Aphasia } \\
\hline Yes & 21 & 11.0 \\
\hline No & 170 & 89.0 \\
\hline \multicolumn{3}{|l|}{ Limbs weakness } \\
\hline Yes & 144 & 75.4 \\
\hline No & 47 & 24.6 \\
\hline \multicolumn{3}{|l|}{ Dyslipidemia Comorbidities } \\
\hline Yes & 101 & 52.9 \\
\hline No & 90 & 47.1 \\
\hline \multicolumn{3}{|l|}{ Comorbidities of Atrial Fibrillation } \\
\hline Yes & 6 & 3.1 \\
\hline No & 185 & 96.9 \\
\hline \multicolumn{3}{|l|}{ Complications } \\
\hline Yes & 83 & 43.5 \\
\hline No & 108 & 56.5 \\
\hline \multicolumn{3}{|l|}{ Urinary Tract Infection Complications } \\
\hline Yes & 2 & 1.0 \\
\hline No & 189 & 99.0 \\
\hline \multicolumn{3}{|l|}{ Decubitus Complications } \\
\hline Yes & 2 & 1.0 \\
\hline No & 189 & 99.0 \\
\hline \multicolumn{3}{|l|}{ Neuroprotection } \\
\hline Yes & 72 & 37.7 \\
\hline No & 119 & 62.3 \\
\hline \multicolumn{3}{|l|}{ Hospitalization Duration } \\
\hline$>5$ days & 82 & 42.9 \\
\hline$\leq 5$ days & 109 & 57.1 \\
\hline
\end{tabular}

Based on Table II, some variables that were considered significant were the gender (p:0.028), loss of consciousness (p:0.000), aphasia (p:0.007), limb weakness (p:0.020), dyslipidemia comorbidities (p:0.002), decubitus complication (p:0.005) by using fisher's exact test, the duration of hospitalization (p:0.023), meanwhile the record of candesartan therapy as a free variable in this study showed the results of 
being not significant (p:0.294, OR: 1.806, 95\% CI:0.591-5.519), as in other antihypertension types (p:0.961, OR: 0.971, 95\% CI:0.305-3.089). Moreover, the subanalysis was performed in the patients with a history of using only ARB therapy to assess whether the candesartan gave a better result of functional recovery compared to the other ARB medication choices and the results of the analysis in Table III showed that candesartan was not better than other ARB medication options (p:0.505, OR:1.472,95\%CI:0.4704.611).

Invalidity of a history on the use of ARB in patients' functional recovery was in line with the research conducted by Sandset et al. in 2011 involving 2029 patients from 146 centers in nine Northern European countries in a cohort prospective study. This study stated that the analysis of the functional outcome referred to the risk of a poor functional outcome on the given candesartan group (p: 0.048, OR:1.17.95\% CI:1.00-1.38), the researchers even stated that $2 \%$ of the total patients experienced hypotension and renal failure, in which this value is bigger compared to the placebo group that is only $1 \%$ (Sanset et al., 2011).

The activation of central angiotensin II triggered a cerebral ischemia event. When the angiotensin II bound up with AT1 receptor, there would be a sympathetic effect triggered as the occurrence of vasoconstriction, the proliferation of cells and the other AT1 receptor effects, so the use of candesartan would help restore the blood flow during the ischemia that the cerebrovascular autoregulation process with a specific blockade on AT1 receptor became an important mechanism for the brain protection. However, the effectiveness of candesartan in recovering the functional for pre-therapy ischemic stroke patients was highly influenced by the state of blood-brain barrier on each patient. As described by Pelisch et al. (2010), candesartan had a limitation in penetrating the blood-brain barrier that was highly dependent on the dose, at the time allotment and liposoluble compounds, whereas the hypertension potentially caused cerebral ischemia and, on such circumstances, the angiotensin II was found that worsening the state due to unavoidable AT1 receptor activation (Pelisch et al., 2010). Candesartan itself had a low bioavailability, i.e. $40 \%$, and it would be eliminated once it was injected to the blood systemic circulation mainly in the kidneys. The effective use of candesartan clinical dose ranged between 8 up to $32 \mathrm{mg}$ per day, in which the monotherapeutic response levels of candesartan would rise up as the dose increased, but the absorption of candesartan never exceeded $60 \%$ so this would affect the efficacy of candesartan in pre-stroke therapy (Seltzer et al., 2004).

Table II. Predictive Factors of Functional Recovery of Ischemic Stroke Patients

\begin{tabular}{|c|c|c|c|c|c|}
\hline Variables & $\mathrm{mRS}<2(\mathrm{n}=152)$ & $m R S \geq 2(n=39)$ & OR & $95 \% \mathrm{CI}$ & $\mathrm{p}$ \\
\hline \multicolumn{6}{|l|}{ Candesartan Record } \\
\hline Yes & $26(13.6 \%)$ & $4(2.1 \%)$ & 1.806 & $\begin{array}{c}0.591- \\
5.519 \\
\end{array}$ & 0.294 \\
\hline No & $126(66.0 \%)$ & $35(18.3 \%)$ & & & \\
\hline \multicolumn{6}{|c|}{ Non- Candesartan Anti-hypertension Record } \\
\hline Yes & $136(71.2 \%)$ & $35(18.3 \%)$ & 0.971 & $\begin{array}{c}0.305- \\
3.089 \\
\end{array}$ & 0.961 \\
\hline No & $16(8.4 \%)$ & $4(2.1 \%)$ & & & \\
\hline Age (years old) & & & & & 0.764 \\
\hline$<40$ & $2(1.0 \%)$ & $0(0.0 \%)$ & Reff & Reff & \\
\hline $40-50$ & $27(14.1 \%)$ & $5(2.6 \%)$ & 1.56 & $0-23.56$ & \\
\hline
\end{tabular}


Jurnal Farmasi Sains dan Komunitas, 2018, 15(1), 37-46

\begin{tabular}{|c|c|c|c|c|c|}
\hline $51-60$ & $45(23.6 \%)$ & $11(5.8 \%)$ & 1.28 & $0-16.27$ & \\
\hline $61-70$ & $47(24.6 \%)$ & $12(6.3 \%)$ & 1.23 & $0-15.47$ & \\
\hline$>70$ & $31(16.2 \%)$ & $11(5.8 \%)$ & 0,89 & 0 & \\
\hline Gender & & & & & 0.028 \\
\hline Male & $92(48.2 \%)$ & $16(8.4 \%)$ & 0.454 & $0.222-0.928$ & \\
\hline Female & $60(31.4 \%)$ & $23(12.0 \%)$ & & & \\
\hline Onset & & & & & 0.29 \\
\hline$<3$ hours & $26(13.6 \%)$ & $8(4.2 \%)$ & Reff & Reff & \\
\hline 3-6 hours & $46(24.1 \%)$ & $15(7.9 \%)$ & 0.94 & $0.31-2.79$ & \\
\hline $6-12$ hours & $38(19.9 \%)$ & $11(5.8 \%)$ & 1.06 & $0.33-3.37$ & \\
\hline 12-24 hours & $42(22.0 \%)$ & $5(2.6 \%)$ & 2.58 & $0.67-10.37$ & \\
\hline Decreased of Consciousness & & & & & $<0.001$ \\
\hline Yes & $4(2.1 \%)$ & $8(4.2 \%)$ & 0.105 & $0.030-0.370$ & \\
\hline No & $148(77.5 \%)$ & $31(16.2 \%)$ & & & \\
\hline Aphasia & & & & & 0.007 \\
\hline Yes & $12(6.3 \%)$ & $9(4.7 \%)$ & 0.286 & 0.111-0.739 & \\
\hline No & $140(73.3 \%)$ & $30(15.7 \%)$ & & & \\
\hline Limbs Weakness & & & & & 0.02 \\
\hline Yes & $109(57.1 \%)$ & $35(18.3 \%)$ & 0.29 & $0.097-0.864$ & \\
\hline No & $43(22.5 \%)$ & $4(2.1 \%)$ & & & \\
\hline Dyslipidemia Comorbidities & & & & & 0.002 \\
\hline Yes & $89(46.6 \%)$ & $12(6.3 \%)$ & 3.179 & $1.497-6.747$ & \\
\hline No & $63(33.0 \%)$ & $27(14.1 \%)$ & & & \\
\hline Comorbidities Atrial Fibrillation & & & & & 0.425 \\
\hline Yes & $4(2.1 \%)$ & $2(1.0 \%)$ & 0.5 & $0.088-2.835$ & \\
\hline No & $148(77.5 \%)$ & $37(19.4 \%)$ & & & \\
\hline Complications & & & & & 0.985 \\
\hline Yes & $66(34.6 \%)$ & $17(8.9 \%)$ & 0.993 & $0.489-2.019$ & \\
\hline No & $86(45.0 \%)$ & $22(11.5 \%)$ & & & \\
\hline Urinary Tract Infection Complication & & & & & 0.297 \\
\hline Yes & $1(0.5 \%)$ & $1(0.5 \%)$ & 0.252 & $0.015-4.116$ & \\
\hline No & $151(79.1 \%)$ & $38(19.9 \%)$ & & & \\
\hline Decubitus Complications & & & & & 0.005 \\
\hline Yes & $0(0.0 \%)$ & $2(1.0 \%)$ & 0.08 & $0-0.93$ & \\
\hline No & $152(79.6 \%)$ & $37(19.4 \%)$ & Reff & Reff & \\
\hline Neuroprotection & & & & & 0.912 \\
\hline Yes & $57(29.8 \%)$ & $15(7.9 \%)$ & 0.96 & $0.465-1.980$ & \\
\hline No & $95(49.7 \%)$ & $24(12.6 \%)$ & & & \\
\hline Hospitalization Duration & & & & & 0.023 \\
\hline$>5$ days & $59(30.9 \%)$ & $23(12.0 \%)$ & 2.266 & $1.107-4.639$ & \\
\hline$\leq 5$ days & $93(48.7 \%)$ & $16(8.4 \%)$ & & & \\
\hline
\end{tabular}


Table III. Sub Analysis of Candesartan VS ARB Non- Candesartan

\begin{tabular}{|c|c|c|c|c|c|}
\hline Variables & $\begin{array}{l}\mathrm{mRS}<2 \\
(\mathrm{n}=132)\end{array}$ & $\begin{array}{c}\mathrm{mRS} \geq 2 \\
(\mathrm{n}=28)\end{array}$ & OR & $95 \% \mathrm{CI}$ & $\mathrm{p}$ \\
\hline Record of ARB Non- Candesartan & $106(66.3 \%)$ & $24(15.0 \%)$ & 1.472 & $0.470-4.611$ & 0.505 \\
\hline Record of Candesartan & $26(16.3 \%)$ & $4(2.5 \%)$ & & & \\
\hline
\end{tabular}

Table IV. Multivariate Analysis

\begin{tabular}{ccccc}
\hline \multirow{2}{*}{ Outcome } & OR & \multicolumn{2}{c}{$95 \%$ CI } & \multirow{2}{*}{$\mathrm{p}$} \\
\cline { 2 - 4 } & & Lower & Upper & 0.021 \\
\hline Gender & 0.366 & 0.156 & 0.858 & 0.007 \\
\hline Decrease of Consciousness & 0.107 & 0.021 & 0.549 & 0.072 \\
\hline Aphasia & 0.342 & 0.107 & 1.100 & 0.025 \\
\hline Limbs Weakness & 0.236 & 0.067 & 0.834 & 0.019 \\
\hline Dyslipdemia & 2.750 & 1.177 & 6.427 & 0.543 \\
\hline Duration of hospitalization & 1.305 & 0.554 & 3.074 & 0.999 \\
\hline Decubitus Comorbidities & 0.000 & 0.000 & - & 0 \\
\hline
\end{tabular}

Sandset et al. (2015) stated that candesartan recovered the patients' functional outcome, but its efficacy also depended on the type of sub-types of ischemic stroke experienced by the patients, in which a better functional outcome tended to occur on the patients with lesions on the myocardial infarction on the total anterior circulation infarction (TACI) sub type or on the partial anterior circulation infarction (PACI) sub type rather than on lacunar infarction (LACI) (p:0.02). Thus, the pre-stroke hypertension patients who started experiencing ischemic on the anterior circulation on either partial or total would be greatly helped with the use of candesartan because if there was a bigger infarction on TACI and PACI, the patients became vulnerable to the development of cerebral edema or the possibility of the hemorrhage occurrence. This type of infraction was more commonly caused by atherothrombotic or acrdioembolic that were supported by the prevalence of atrial fibrillation which was higher for the patients with this infarction sub type. Thus, it made sense if reducing the blood pressure on this sub type would avoid the risk, even though the candesartan in doing brain protection was not as simple as reducing the patients' blood pressure. As explained in the previous chapter, the candesartan just blocked the AT1 receptor so it meant that AT2 receptor that had an opposite working mechanism would greatly help protect the brains. Most patients who experienced LACI were chronic hypertension sufferers who eventually showed an autoregulation ability in regulating brain blood regulation. It was believed that reducing the blood pressure would cause blood perfusion deficits broadly on the brain because the blood flow became inadequate in doing brain tissue perfusion (Sandset et al., 2015). On the other hand, these things were the reasons why the patients with the candesartan record did not show functional outcome improvement. In this research, the dose of therapy and the obedience of each patient could not be researched, as supported by the candesartan's limitation in penetrating the blood-brain barrier and the wide ischemic that occurred when the patient experienced hypertension.

The results of this study indicated that the male patients had lower functional outcome probability than female patients. This contrasted to the $\mathrm{Ng}$ et al. (2013) who stated that female patients had worse post-stroke physical ability than male patients who were able to do physical activity independently (HR: 0.51, 95\%CI:0.32-0.79). The researcher stated that the pre-stroke physical function and 
the symptoms of depression were important factors in the different results of the both gender recovery ( $\mathrm{Ng}$ et al., 2013). Some researches indicated that female experienced more severe stroke compared to male even though other studies indicated that there was no significant difference in both genders. The International Stroke Trial found that the incidence of death on female was high in 6 months after the stroke. This was corroborated by Gargano and Reeves (2007) who agreed that female had lower functional outcome and a poor quality of life compared to male after a devastating stroke. Meanwhile, The Women's Health Organization MONICA Project found that within 28 days of observation on ischemic stroke patients, the mortality rate of female was on par or higher than male. However, it was in contrast to the latest research from Framingham Heart Study which found that there was no significant difference on mortality of both genders. The fundamental difference between male and female such as age, comorbidity, severity, and pre-stroke disability commonly caused deaths on female, but even when these factors had been controlled, female still had worse functional outcome (Gargano and Reeves, 2007; Persky et al., 2010; Min et al., 2005).

Patients who experienced aphasia independently had probability of having good functional outcome 0.342 times compared to those who did not experience it (0R:0.342), however, Maas et al. (2012) stated that the evaluation results of ischemic stroke patients who suffered aphasia after 6 months would have a recovery of $86 \%$ and $74 \%$ (Maas et al., 2012). Based on the results of the multivariate analysis (Table IV), it was clearly presented that the patients entering the hospital with decreased consciousness had the probability of having worse functional outcome than those who did not experience it (OR:0.107), Tsao et al. (2005) in their study stated that the patients with a good level of consciousness during the attack was related with a good functional outcome of the patients (Tsao et al., 2005). The patients who enter the hospital with decreased consciousness described the stroke severity they experienced and the wider lesions, the more severe brain hypoxia occurred so that this would influence the extent of the penumbra that could be saved in order to get the patients a better functional outcome.

Patients with dyslipidemia had the 2.75 times probability of having a good functional outcome compared to those who did not experience it. Out of the patients with dyslipidemia comorbidities, 89 patients had a good functional outcome while 12 patients had a bad functional outcome. In the patients without comorbidities, there were 63 patients with a good functional outcome and 27 patients with a bad functional outcome. A study on meta-analysis in 2007 stated that the total number of cholesterol did not take part significantly on the mortality of the ischemic stroke patients aged 40-59 years. However, it was strongly influenced by the patients' blood pressure. For the patients with blood pressure more than $145 \mathrm{mmHg}$, their cholesterol did not strongly affect the patients' mortality. It was estimated to be due to vascular collaterals on the brains, but a meta-analysis stated that decreasing the cholesterol levels might reduce the risk of stroke (Lewington et al., 2008). The multivariate analysis showed that the limb weakness was strongly affected by bad functional outcome (OR:0.236). Gray et al. (2012) stated that after a stroke, the patients would spend more than $50 \%$ of their time lying down. This inactivity caused sarcopenia to occur. Sarcopenia is the state in which the patients lose their muscle mass causing them to gain more fat mass in the body. Within 2 weeks of inactivity, it had already caused the loss of muscle mass and its strength. Thus, the damage caused by stroke and immobility would simultaneously cause the loss of muscle mass and impact on the patients' independence in doing physical activities (Gray et al., 2012).

Long hospitalization did not improve the patients' functional outcome. This finding was contradicted by Bindawas et al. (2016) who stated that patients who were hospitalized for a long time were closely related to comorbid disease that accompanied it. Therefore, it was common that the patients' 
functional outcome became worse, whereas the patients with a short and medium time of hospitalization had better functional outcome. In this state, the patients were considered as having an efficient medication so that they had shorter time of hospitalization. However, the decision regarding to the length of hospitalization extremely varied to adjust to the type of insurance service applied by the corresponding health services so that it was reasonable that the duration of hospitalization could not be a specific benchmark in determining the patients' functional outcome when they were out of the hospital. The length of hospitalization could usually be prolonged under a certain condition of the patients. Wang et al. (2014) concluded that the patients who underwent a decubitus rehabilitation would experience motor skill declining and likely to enter into the community (Wang et al., 2014; Bindawas et al., 2016).

\section{CONCLUSION}

Based on the analysis and the discussion above, it is concluded that the use of candesartan therapy before the onset of stroke does not affect patients' clinical improvement after a stroke.

\section{REFERENCES}

Bindawas, S.M., Mawajdeh, H., Vennu, V., and Alhaidary, H., 2016. A retrospective observational study of functional outcomes, length of stay, and discharge disposition after an inpatient stroke rehabilitation program in Saudi Arabia. Medicine (Baltimore), 95(31), e4432.

Center for Disease Control and Prevention, 2016. Top 10 Causes of Death [online]. Center for Disease Control and Prevention. Available from: https://www.cdc.gov/globalhealth/countri es/indonesia/default.htm [Accessed 10 October 2017].

Chrysant, S.G., and Chrysant, G.S., 2006. The pleiotropic effects of angiotensin receptor blockers. The Journal of Clinical Hypertension, 8, 261-268.

Gargano, J.W., and Reeves, M.J., 2007. Sex Differences in Stroke Recovery and
Stroke-Specific Quality of Life: Results from a Statewide Stroke Registry. Stroke, 38, 2541-2548.

Gray, V., Rice, C.L., and Garland, S.J., 2012. Factors That Influence Muscle Weakness Following Stroke and Their Clinical Implications: A Critical Review. Physiotherapy Canada, 64 (4), 415-426.

Kusuima, Y., Venketasubramanian, N., Kiemas, L.S., and Misbach, J., 2009. Burden of stroke in indonesia. World Stroke Organization International Journal of Stroke, 4, 379-380.

Lewington, S., Whitlock, G., Clarke, R., Sherliker, P., Emberson, J., Halsey, J., Qizilbash, N., Peto, R., and Collins, R., 2008. Blood cholesterol and vascular mortality by asulivange, sex, and blood pressure: a meta-analysis of individual data from 61 prospective studies with 55,000 vascular deaths. The Lancet, 370 (9602), 1829-1839.

Maas, M.B., Lev, M.H., Ay, H., Singhal, A.B., Greer, D.M., Smith, W.S., Harris, G.J., Halpern, E.F., Koroshetz, W.J., and Furie, K.L., 2012. The Prognosis for Aphasia in Stroke. Journal of Stroke and Cerebrovascular Diseases, 21 (5), 350357.

Min, L.S., Duncan, P.W., Dew, P., and Keighley, J., 2005. Sex Differences in Stroke Recovery. Preventing Chronic Disease Public Health Research, Practice, And Policy, 2 (3), 1-11.

Ng, Y.S., Astrid, S., Silva, D.A.D., Tan, M.L.D., Tan, Y.L., and Chew, E., 2013. Functional Outcomes after Inpatient Rehabilitation in a Prospective Stroke Cohort. Proceedings of Singapore Healthcare, 22 (3), 175-182.

Pelisch, N., Hosomi, N., Ueno, M., et al., 2010. Systemic candesartan reduces brain angiotensin II via downregulation of brain renin-angiotensin system. Hypertension Research, 33 (2), 161-4.

Persky, R.W., Turtzo, L.C., McCullough, L.D., 2010. Stroke in Women: Disparities and Outcomes. Current Cardiology Reports, 12 (1), 6-13. 
Riset Kesehatan Dasar, 2013. Jakarta: Badan Penelitian dan Pengembangan Kesehatan, Departemen Kesehatan, Republik Indonesia.

Sandset, E.C., Bath, P.M.W., Boysen, G., Jatuzis, D., Korv, J., Luders, S., Murray, G.D., Richter, P.S., Roine, R.O., Terent, A., Thijs, V., and Berge, E., 2011. The angiotensin-receptor blocker candesartan for treatment of acute stroke (SCAST): a randomised, placebo-controlled, doubleblind trial. The Lancet, 377 (9767), 741750.

Sandset, EC., Jusufovic, M., Sandset, PM., Bath, PMW., and Berge, E., 2015. Effects of blood pressure-lowering treatment in different subtypes of acute ischemic stroke. Stroke, 46, 877-879.

Seltzer, A., Bregonzio, C., Armando, I., et al. 2004. Oral administration of an AT1 receptor antagonist prevents the central effects of angiotensin II in spontaneously hypertensive rats. Brain Research, 1028(1), 9-18.

Sullivan, K.M., and Soe, M.M., 2007. Documentation for Sample Size for a Cross-Sectional, Cohort, or Clinical Trial Studies.

Tsao, J.W., Hemphill, J.C., Johnston, S.C., Smith, W.S., and Bonovich, D.C., 2005.
Initial Glasgow Comma Scale Score Predicts Outcome Following Thrombolysis for Posterior Circulation Stroke. Archives of Neurology, 62 (7), 1126-1129.

Tziomalos, K., Bouziana, S., Spanou, M., Papadopoulou, M., Giampatzis, V., Kazantzidou, P., Dourliou, V., Kostaki, S., Savopoulos, C., and Hatzitolios, A., 2014. Angiotensin receptor blockers improve functional outcome and reduce all-cause mortality in patients discharged after acute ischemic stroke. Journal of The American Society of Hypertension, 8(4), Suppl, e139.

Wang, H., Niewczyk, P., Divita, M., Camicia, M., Appelman, J., Mix, J., and Sandel, ME., 2014. Impact of pressure ulcers on outcomes in inpatient rehabilitation facilities. American Journal of Physical Medicine \& Rehabilitation, 93 (3), 207 216.

Yayasan Stroke Indonesia, 2016. Stroke penyebab kematian urutan pertama di rumah sakit Indonesia [online]. YASTROKI. Available from: http://www.yastroki.or.id/read.php?id=27 6 [Accessed 10 December 2016]. 